\title{
INFLUENCE OF STORAGE TEMPERATURES AND STORAGE TIME OF DRY LEAVES ON PATCHOULI [Pogostemon cablin (Blanco) Benth.] ESSENTIAL OIL
}

\author{
INFLUENCIA DO TEMPO E TEMPERATURAS DE ARMAZENAMENTO DAS \\ FOLHAS SECAS NO ÓLEO ESSENCIAL DE PATCHOULI [Pogostemon cablin \\ (Blanco) Benth.]
}

\begin{abstract}
Maria de Fátima ARRIGONI-BLANK ${ }^{\mathbf{1}}$; Priscila Santana SANTOS ${ }^{\mathbf{1}}$; Arie Fitzgerald BLANK ${ }^{\mathbf{1}}$; Fabiany de Andrade Brito ${ }^{1}$; Thiago Matos ANDRADE ${ }^{1}$; Daniela Aparecida de Castro NIZIO ${ }^{1}$; Péricles Barreto ALVES ${ }^{2}$

1. Departamento de Engenharia Agronômica, Universidade Federal de Sergipe, São Cristóvão, SE, Brasil, fatima.blank@gmail.com;

2. Departamento de Química, Universidade Federal de Sergipe, São Cristóvão, SE, Brasil
\end{abstract}

\begin{abstract}
Patchouli [Pogostemon cablin (Blanco) Benth.] is a plant of the family Lamiaceae, widely used as an essential oil in the cosmetics and perfumery industry. This study aimed to evaluate the influence of storage time and temperature of dry leaves on the patchouli essential oil content and chemical composition. The experiment was performed in a completely randomized design in a $6 \times 2 \times 2$ factorial scheme, testing storage time $\left(0,1,2,4,8\right.$, and 16 weeks) and temperature $\left(28^{\circ} \mathrm{C}\right.$ and $\left.33^{\circ} \mathrm{C}\right)$ of dry leaves of two patchouli genotypes (POG-015 and POG-021). The variables essential oil content and chemical composition, and the identification of fungus during storage were evaluated. Results showed that the storage significantly influenced the essential oil content. Patchoulol was identified as the major compound in both genotypes, ranging from $55.05 \%$ to $68.77 \%$ (POG-15) and from $52.83 \%$ to $64.06 \%$ (POG-021). Based on the results of patchoulol, dry leaves of both genotypes (POG-015 and POG-021) can be stored for up to eight weeks at 28$33^{\circ} \mathrm{C}$ without altering the essential oil quality.
\end{abstract}

KEYWORDS: Pogostemon cablin. Postharvest. Patchoulol. Chemical composition.

\section{INTRODUCTION}

Patchouli [Pogostemon cablin (Blanco) Benth] is an aromatic plant of the family Lamiaceae (ANONIS, 2006) that naturally occurs in Southeast Asia, where it is widely used in traditional medicine (SWAMY; SINNIAH, 2015). The essential oil of this species can be used for several purposes, such as aromatherapy (SALERNO; REBELO; SILVA JUNIOR, 2004), insecticide (PAVELA, 2005), and insect repellent (ZHU et al., 2003; SALERNO; REBELO; SILVA JUNIOR, 2004; ALBUQUERQUE et al., 2013).

Patchouli essential oil stands out in the perfumery industry (SINGH; SHARMA; RAMESH, 2002) for providinga base and lasting character to a fragrance, and is among the 18 most important essential oils worldwide (BIZZO; HOVELL; REZENDE, 2009).

The chemical composition of patchouli essential oil varies according to the genotype, production organs, environmental and production conditions, and storage conditions. However, patchoulol and $\alpha$-patchoulene are considered the most important compounds and aroma regulators
(SINGH; SHARMA; RAMESH, 2002). Patchoulol is a sesquiterpene officially used as a chemical marker for the quality assessment of Pogostemonis Herba in the Chinese Pharmacopoeia. Tsai et al. (2007) reported that leaf material quality, dry leaf, essential oil aging, and plant age could also influence the quality of patchouli essential oil. A review study has shown that when considering 100 analyses of patchouli essential oils, the authors listed the main compounds and their observed average concentrations, such as patchoulol (39.0\%), $\alpha$-bulnesene $\quad(14.0 \%), \quad \alpha$-guaiene $\quad(11.0 \%)$, seyclellene $(6.6 \%), \alpha$-patchoulene $(4.5 \%)$, (E) $-\beta$ caryophyllene $(3.1 \%), \beta$-patchoulene and pogostol (2.4\%) (BEEK; JOULAIN 2018).

Nizio et al. (2018) reported that, in general, the stages that follow the plant material harvest, such as the drying process, the storage of plant material, and the extraction process could influence the essential oil content and chemical composition. Leaf drying and the appropriate storage allow better plant material conservation. Thus, the drying process is widely used, but it must be performed in a way that does not compromise the product quality at the end of the production process (MARCHESE; 
FIGUEIRA, 2005). In a study with Myrcia lundiana, Alves et al. (2018) reported that one-day drying at $40{ }^{\circ} \mathrm{C}$ was enough to dry the leaves without affecting the essential oil content.

In the case of aromatic species, the drying process must consider the storage structure and the volatile characteristics of the essential oil compounds. Drying is used to prevent microorganisms reproduction, consequently preserving the quality of the harvested plant. It also reduces the weight and volume of plants for transportation and storage (CORREA et al., 2004). Sant'ana et al. (2010) observed that the dry leaves of two patchouli genotypes stored for 28 days had an increase in the essential oil content. The novelty of the present study is the storage time and the comparison of the percentages of the main compounds at those storage times.

Due to the importance of patchouli essential oil, this study aimed to evaluate the effect of the storage time and temperature of dry leaves on the essential oil content and chemical composition.

\section{MATERIAL AND METHODS}

\section{Plant material and experimental design}

This study used two patchouli genotypes (POG-015 and POG-021) from the Active Germplasm Bank of Medicinal and Aromatic Plants of the Federal University of Sergipe. The exsiccates are deposited in the Herbarium of the Department of Biology, under the numbers 13173 and 13177.

Seedlings of the two genotypes were generated by cutting, in black plastic bags. Vermiculite and coconut coir dust (1:1) were used as the substrate and were supplemented with 1 g. $\mathrm{L}^{-1}$ of lime and $2 \mathrm{~g} . \mathrm{L}^{-1}$ of N-P-K (6 -24-12). Seedlings were transferred to a greenhouse (50\% shaded), with an intermittent misting, at the Department of Agronomic Engineering of UFS, where they were kept until transplanting. At 40 days after planting, seedlings were transplanted to the field (January 2011).

Seedlings were planted at the Experimental Farm "Campus Rural da UFS", located in the municipality of São Cristóvão, Sergipe (lat. $11^{\circ} 00^{\prime} \mathrm{S}$; long. $37^{\circ} 12^{\prime} \mathrm{W}$ ), in a Red-Yeallow Argisol. The soil had the following chemical and physical characteristics: water $\mathrm{pH}-5.4 ; \mathrm{P}-23.3 \mathrm{mg} . \mathrm{dm}^{-3} ; \mathrm{K}$ 0.09 cmolc. $\mathrm{dm}^{-3} ; \mathrm{Ca}+\mathrm{Mg}-2.70$ cmolc. $\mathrm{dm}^{-3} ; \mathrm{Al}=$ 0.48 cmolc. dm $^{-3} ; \mathrm{Zn}-1.09$ cmolc. $\mathrm{dm}^{-3} ; \mathrm{Cu}-0.68$ cmolc. dm ${ }^{-3} ; \mathrm{Fe}-990.0$ cmolc.dm ${ }^{-3} ; \mathrm{Mn}-1.14$ mg. $\mathrm{dm}^{-3}$; O.M - 21 g.dm ${ }^{-3}$; and V - 58.1\%.

The soil $\mathrm{pH}$ was corrected to 6.5 , using dolomitic lime. Fertilization consisted of applying
6L. $\mathrm{m}^{-2}$ of bovine manure and $160 \mathrm{~g} . \mathrm{m}^{-2}$ of N-P-K (624-12) + micronutrients. The spacing was $0.50 \mathrm{~m}$ between plants and $0.60 \mathrm{~m}$ between rows. Drip irrigation was used, and plants were cultivated in double-colored plastic mulch (black on the bottom and white on the top).

In May 2011, shoots were harvested at 25 $\mathrm{cm}$ from the soil, and leaves were dried in a forcedair-circulation oven at $38{ }^{\circ} \mathrm{C}$, for five days. Then, the shoot dry matter per plant was determined. Dry leaves were randomly separated into 60-gram lots and packed in black plastic bags. Leaves were stored in a BOD chamber, in the darkness, for 0,1 , $2,4,8$, and 16 weeks, at 28 and $33^{\circ} \mathrm{C}$.

The experiment was carried out in a completely randomized design, in a $6 \times 2 \times 2$ factorial scheme, with six storage periods $(0,1,2,4,8$, and 16 weeks), two Genotypes (POG-015 and POG021), and two temperatures $\left(28\right.$ and $\left.33^{\circ} \mathrm{C}\right)$, with three replications.

\section{Essential oil extraction}

Three 50g dry leaves samples were collected in the storage period for the essential oil extraction. The metabolite was extracted by hydrodistillation, in a Clevenger apparatus coupled to a $3,000 \mathrm{~mL}$ round-bottomed glass flask, for 160 minutes. The flask was added with $2,000 \mathrm{~mL}$ of distilled water and $50 \mathrm{~g}$ of dry leaves (EHLERT et al., 2006). Contents were estimated based on the dry mass $\left(\mathrm{mL}^{1} 100 \mathrm{~g}^{-1}\right)$ and expressed in percentage. Essential oil samples were kept in capped amber glass flasks, in a freezer, until chemical analysis.

\section{Essential oil chemical analysis}

The qualitative analysis of the essential oil chemical composition was performed in a gas chromatograph coupled to a GC-MS mass spectrometer (Shimadzu, model QP 5050A) with an autosampler (AOC-20i, Shimadzu), and a J \& W Scientific fused silica capillary column (5\%diphenyl-95\%-dimethylpolysiloxane) of $30 \mathrm{~m}$ x 0.25 $\mathrm{mm}$ i.d., $0.25 \mu \mathrm{m}$ film thickness, at a constant helium flow rate of $1.2 \mathrm{~mL} / \mathrm{min}$. The temperature was set to $50^{\circ} \mathrm{C}$ for $1.5 \mathrm{~min}$, then programmed to increase to $200^{\circ} \mathrm{C}$ at $4{ }^{\circ} \mathrm{C} / \mathrm{min}$, followed by an increase of $15^{\circ} \mathrm{C} / \mathrm{min}$ up to $250^{\circ} \mathrm{C}$, then remaining constant for $5 \mathrm{~min}$. The sampler temperature was $250^{\circ} \mathrm{C}$, and the detector temperature was $280{ }^{\circ} \mathrm{C}$. The injection volume was $0.5 \mu \mathrm{L}$ (ethyl acetate), with a split ratio of 1: 100 and a column pressure of $64.20 \mathrm{kPa}$. The MS conditions consisted of an ionic capture detector with an electron energy of $70 \mathrm{eV}$. The scanning speed was 1,000 , at a scan rate of 0.3 $\mathrm{scan} / \mathrm{s}$, and the system was programmed to scan 
Influence of storage...

fragments/ions with $\mathrm{m} / \mathrm{z}$ in the order of 40 to 500 Da.

The essential oil components were identified by matching their mass spectra to the spectra available in the database of the device (NIST05, NIST21, and WILEY8). These libraries allowed for the comparison of spectral data with a similarity index above $80 \%$. The measured retention indices were also compared with indices from the literature (ADAMS, 2007). The Kovats retention indices (KI) were determined by a homologous series of n-alkanes $\left(\mathrm{C}_{8}-\mathrm{C}_{18}\right)$ injected under the same chromatographic conditions of the samples, using the equation of Van Den Dool and Kratz (1963).

The quantitative analysis of the essential oil compounds was performed by Gas Chromatography/Mass Spectrometry and Flame Ionization Detector - GC/MS/FID (Shimadzu GC17A), coupled with a ZB-5MS fused silica capillary column (5\% dimethylpolysiloxane), with $30 \mathrm{~m} \mathrm{x}$ $0.25 \mathrm{~mm}$ i.d., $0.25 \mu \mathrm{m}$ film thickness, under the same GC-MS conditions. Compounds were quantified by area normalization $(\%)$. Compounds concentrations
ARRIGONI-BLANK, M. F. et al.

were calculated by the area and placed in order of $\mathrm{GC}$ elution.

\section{Statistical analyses}

Variables means were subject to analysis of variance and compared by the Scott-Knott test at the $5 \%$ probability level and polynomial regression, using the Sisvar software (FERREIRA, 2011).

\section{RESULTS AND DISCUSSION}

A triple interaction (genotype $\mathrm{x}$ storage time $\mathrm{x}$ storage temperature of leaves) was detected in the essential oil content. The essential oil content of genotype POG-021 varied when the leaves were stored at $28{ }^{\circ} \mathrm{C}$. This variation is represented by a quadratic equation, in which the highest levels were obtained between the second and eighth weeks of storage. At this same temperature $\left(28^{\circ} \mathrm{C}\right)$, no significant differences were observed for genotype POG-015. At $33^{\circ} \mathrm{C}$ results for both genotypes can be represented by quadratic equations, and contents ranged from $2.13 \%$ to $3.0 \%$ (POG-015) and from $2.43 \%$ to $3.0 \%$ (POG-021) (Table 1 ).

Table 1. Essential oil content of Patchouli (Pogostemon cablin) genotypes in function of storage time and storage temperature of dry leaves.

\begin{tabular}{|c|c|c|c|c|c|c|c|}
\hline \multirow{3}{*}{ Genotype } & \multicolumn{6}{|c|}{ Essential oil content $(\%)$} & \multirow[b]{3}{*}{ Equation $\mathrm{Y}=$} \\
\hline & \multirow[b]{2}{*}{$\mathbf{0}$} & \multicolumn{3}{|c|}{ Time (weeks) } & \multirow[b]{2}{*}{8} & \multirow[b]{2}{*}{16} & \\
\hline & & 1 & 2 & 4 & & & \\
\hline & ---------. & ---------- & ------ 28 & ---------- & ----------- & & \\
\hline POG-015 & $2.40 \mathrm{aA}$ & $3.27 \mathrm{aA}$ & $2.60 \mathrm{bA}$ & $2.60 \mathrm{bA}$ & $2.73 \mathrm{bA}$ & $2.30 \mathrm{bA}$ & ns \\
\hline POG-021 & $2.60 \mathrm{aA}$ & $3.07 \mathrm{aA}$ & $3.60 \mathrm{aA}$ & $3.47 \mathrm{aA}$ & $3.60 \mathrm{aA}$ & $2.93 \mathrm{aA}$ & $\begin{array}{l}2.8431+0.2197 \mathrm{x}-0.0135 \mathrm{x}^{2} \\
\mathrm{R}^{2}=73.95 \%\end{array}$ \\
\hline & ---------. & - & ----- 33 & --------- & --------- & & \\
\hline POG-015 & $2.40 \mathrm{aA}$ & $2.87 \mathrm{aA}$ & $2.87 \mathrm{aA}$ & $2.73 \mathrm{aA}$ & $3.00 \mathrm{aA}$ & $2.13 \mathrm{aA}$ & $\begin{array}{l}2.556+0.1262 \mathrm{x}-0.0095 \mathrm{x}^{2} \\
\mathrm{R}^{2}=81.16\end{array}$ \\
\hline POG-021 & $2.60 \mathrm{aA}$ & $3.00 \mathrm{aA}$ & $2.87 \mathrm{aB}$ & $2.93 \mathrm{aB}$ & $3.00 \mathrm{aB}$ & $2.43 \mathrm{aA}$ & $\begin{array}{l}2.7303+0.0879 \mathrm{x}-0.0066 \mathrm{x}^{2} \\
\mathrm{R}^{2}=80.30 \%\end{array}$ \\
\hline
\end{tabular}

$\mathrm{CV}(\%)$

11.21

São Cristóvão (SE), UFS, 2012; Means followed by the same lowercase letters in the column and uppercase letter between temperatures do not differ by the Scott-Knott's test $(\mathrm{p} \leq 0.05)$.

Sant'ana et al. (2010) reported the beneficial effect on the essential oil content provided by the storage of patchouli leaves for 28 days. The authors verified an increase from 1.60 to $2.7 \%$ in the essential oil content, depending on the genotype. They also detected 14 chemical compounds in two patchouli genotypes.

The highest percentages of essential oil compounds in the two storage temperatures were reported for patchoulol, with values ranging from 52.04 to $68.77 \%$ (POG-015) and from 52.83 to $64.06 \%$ (POG-021); $\alpha$-bulnesene, with values ranging from 6.48 to $10.20 \%$ (POG-015) and from 5.71 to $9.67 \%$ (POG-021); pogostol, with values ranging from 5.45 to $7.72 \%$ (POG-015); and $\alpha$ guanene, with values ranging from 4.14 to $7.20 \%$ (POG-015) and from 5.30 to $7.16 \%$ (POG-021).

Considering $\beta$-patchoulene, the highest content $(1.46 \%)$ reported for genotype POG-015 was obtained around the fourth week of leaves storage at $28^{\circ} \mathrm{C}$. Conversely, for genotype POG021 , at the same temperature, the highest content $(1.85 \%)$ was recorded in the sixteenth week of storage. The analysis of genotype POG- 021 at $33^{\circ} \mathrm{C}$ 
Influence of storage...

showed no significant differences throughout the storage period. The same was observed for $\beta$ elemene and cycloseychellene (Table 2).

E-caryophyllene contents ranged from $1.07 \%$ in the eighth week to $2.10 \%$ in the second week (POG-015, at $28^{\circ} \mathrm{C}$ ). For POG-021, the contents varied between $1.30 \%$ (eighth week) and $2.06 \%$ (first week) at $33^{\circ} \mathrm{C}$. At $28^{\circ} \mathrm{C}$, results for both genotypes are represented by cubic equations (Table 3).
ARRIGONI-BLANK, M. F. et al.

In relation to $\alpha$-guanene, contents were slightly higher when compared with those of E-caryophyllene, ranging from 4.14 to $7.20 \%$ (POG-015). For seychellene, the lowest contents were recorded in the eighth week for POG-015, at the two temperatures tested; conversely, the highest contents were registered for POG-021, in the sixteenth week, with no significant difference between the two temperatures (Table 3 ).

Table 2. Contents of the chemical compounds $\beta$-patchoulene, $\beta$-elemene, and cycloseychellene of the essential oil of Patchouli (Pogostemon cablin) genotypes in function of storage time and storage temperatures of dry leaves.

\begin{tabular}{|c|c|c|c|c|c|c|c|}
\hline \multirow[t]{2}{*}{ Genotype } & \multicolumn{6}{|c|}{ Storage (weeks) } & \multirow[b]{2}{*}{ Equation $Y=$} \\
\hline & $\mathbf{0}$ & 1 & 2 & 4 & 8 & 16 & \\
\hline & \multicolumn{6}{|c|}{$\beta$-patchoulene (RRI: 1379) } & \\
\hline POG-015 & $1.13 \mathrm{aA}$ & $1.14 \mathrm{aA}$ & $1.17 \mathrm{Aa}$ & $1.46 \mathrm{aA}$ & $0.77 \mathrm{aA}$ & $1.12 \mathrm{bA}$ & $\begin{array}{l}1.0354+0.2282 \mathrm{x}- \\
0.0501 \mathrm{x}^{2}+0.0022 \mathrm{x}^{3} \\
\mathrm{R}^{2}=73.38 \%\end{array}$ \\
\hline POG-021 & $1.34 \mathrm{aA}$ & $1.08 \mathrm{aB}$ & $1.24 \mathrm{aA}$ & $0.98 \mathrm{bA}$ & $1.08 \mathrm{aA}$ & $1.85 \mathrm{aA}$ & $\begin{array}{l}1.2892-0.0949 x+0.0081 x^{2} \\
R 2=93.38 \%\end{array}$ \\
\hline POG-015 & $1.13 \mathrm{aA}$ & $1.29 \mathrm{bA}$ & $1.20 \mathrm{aA}$ & $1.07 \mathrm{aB}$ & $0.80 \mathrm{bA}$ & $1.08 \mathrm{bA}$ & $\begin{array}{l}1.2752-0.0820 \mathrm{x}+0.0042 \mathrm{x}^{2} \\
\mathrm{R}^{2}=65.97 \%\end{array}$ \\
\hline POG-021 & $1.34 \mathrm{aA}$ & $1.76 \mathrm{aA}$ & $1.36 \mathrm{aA}$ & $1.07 \mathrm{aA}$ & $1.40 \mathrm{aA}$ & $1.46 \mathrm{aB}$ & Ns \\
\hline \multirow[t]{2}{*}{ CV (\%) } & \multicolumn{6}{|c|}{16.23} & \\
\hline & \multicolumn{6}{|c|}{$\beta$-elemene (RRI: 1389) } & \\
\hline POG-015 & $0.57 \mathrm{aA}$ & $0.60 \mathrm{aA}$ & $0.63 \mathrm{aA}$ & $0.62 \mathrm{aA}$ & $0.30 \mathrm{aA}$ & $0.38 \mathrm{aA}$ & $\begin{array}{l}0.5525+0.0899 \mathrm{x}- \\
0.0238 \mathrm{x}^{2}+0.0010 \mathrm{x}^{3} \\
\mathrm{R}^{2}=98.97 \%\end{array}$ \\
\hline POG-021 & $0.43 \mathrm{bA}$ & $0.46 \mathrm{bA}$ & $0.37 \mathrm{bA}$ & $0.49 \mathrm{bA}$ & $0.32 \mathrm{aA}$ & $0.44 \mathrm{aA}$ & ns \\
\hline POG-015 & $0.57 \mathrm{aA}$ & $0.58 \mathrm{aA}$ & $0.64 \mathrm{aA}$ & $0.49 \mathrm{aB}$ & $0.33 \mathrm{aA}$ & $0.38 \mathrm{aA}$ & $\begin{array}{l}0.6286-0.0460 x+0.0018 x^{2} \\
R^{2}=79.51 \%\end{array}$ \\
\hline POG-021 & $0.43 \mathrm{bA}$ & $0.51 \mathrm{bA}$ & $0.36 \mathrm{bA}$ & $0.44 \mathrm{aA}$ & $0.31 \mathrm{aA}$ & $0.39 \mathrm{aA}$ & ns \\
\hline \multirow[t]{2}{*}{ CV $(\%)$} & & & & .01 & & & \\
\hline & \multicolumn{6}{|c|}{ Cycloseychellene (RRI: 1406) } & \\
\hline POG-015 & $0.26 \mathrm{aA}$ & $0.28 \mathrm{aA}$ & $0.29 \mathrm{aA}$ & $0.34 \mathrm{aA}$ & $0.46 \mathrm{aA}$ & $0.23 \mathrm{bA}$ & $\begin{array}{l}0.2333+0.0471 \mathrm{x}-0.0029 \mathrm{x}^{2} \\
\mathrm{R}^{2}=86.87 \%\end{array}$ \\
\hline POG-021 & $0.26 \mathrm{aA}$ & $0.31 \mathrm{aA}$ & $0.33 \mathrm{aA}$ & $0.31 \mathrm{aA}$ & $0.34 \mathrm{bA}$ & $0.34 \mathrm{aA}$ & ns \\
\hline & & ----------- & ---------- & $3 \mathrm{C}-$ & ---------- & ------ & \\
\hline POG-015 & $0.26 \mathrm{aA}$ & $0.27 \mathrm{aA}$ & $0.30 \mathrm{aA}$ & $0.26 \mathrm{aA}$ & $0.26 \mathrm{aB}$ & $0.22 \mathrm{aA}$ & ns \\
\hline POG-021 & $0.26 \mathrm{aA}$ & $0.34 \mathrm{aA}$ & $0.25 \mathrm{aA}$ & $0.33 \mathrm{aA}$ & $0.25 \mathrm{aA}$ & $0.30 \mathrm{aA}$ & ns \\
\hline
\end{tabular}

$\mathrm{CV}(\%)$

São Cristóvão (SE), UFS, 2012; Means followed by the same lowercase letters in each column and uppercase letters between temperatures do not differ by the Scott-Knott's test ( $\mathrm{p} \leq 0.05)$.

The contents of $\alpha$-humulene, alloaromadendrene (Table 4), and 9-epi- (E) caryophyllene (Table 6) were below $1.0 \%$. The content of $\alpha$-patchoulene decreased from the eighth week of storage for POG-015 at both temperatures. POG-021 had no significant difference for storage time at 28 and $33{ }^{\circ} \mathrm{C}$ (Table 4). $\alpha$-bulnesene contents ranged from 6.5 to 10\% (POG-015) and from 5.7 to $9.6 \%$ (POG-021) (Table 5). The contents of $\alpha$-bulnesene in POG-015 increased until the fourth week of storage at $28^{\circ} \mathrm{C}$.

The highest patchoulol content in POG-015 was reported in the eighth week of storage $(68.77 \%)$ at $28{ }^{\circ} \mathrm{C}$. Results are represented by cubic equations 
for the two genotypes (Table 6). Sant'ana et al. (2010) also observed that patchoulol concentrations of the essential oil of stored leaves were significantly higher than those of non-stored leaves.

Table 3. Contents of the chemical compounds E-caryophyllene, $\alpha$-guaiene, and seychellene of the essential oil of Patchouli (Pogostemon cablin) genotypes in function of storage time and storage temperatures of dry leaves.

\begin{tabular}{|c|c|c|c|c|c|c|c|}
\hline \multirow[t]{2}{*}{ Genotype } & \multicolumn{6}{|c|}{ Storage (weeks) } & \multirow[b]{2}{*}{ Equation $Y=$} \\
\hline & $\mathbf{0}$ & 1 & 2 & 4 & 8 & 16 & \\
\hline & \multicolumn{6}{|c|}{ E-caryophyllene (RRI: 1417) } & \\
\hline POG-015 & $1.89 \mathrm{aA}$ & $2.02 \mathrm{aA}$ & $2.10 \mathrm{aA}$ & $2.13 \mathrm{aA}$ & $1.07 \mathrm{bA}$ & $1.23 \mathrm{bA}$ & $\begin{array}{l}1.8346+0.3115 \mathrm{x}- \\
0.0791 \mathrm{x}^{2}+0.0035 \mathrm{x}^{3} \\
\mathrm{R}^{2}=98.37 \%\end{array}$ \\
\hline POG-021 & $1.67 \mathrm{aA}$ & $1.85 \mathrm{aA}$ & $1.74 \mathrm{bA}$ & $1.86 \mathrm{bA}$ & $1.48 \mathrm{aA}$ & $1.73 \mathrm{aA}$ & $\begin{array}{l}1.6801+0.1341 \mathrm{x}- \\
0.0312 \mathrm{x}^{2}+0.0014 \mathrm{x}^{3} \\
\mathrm{R}^{2}=82.56 \%\end{array}$ \\
\hline & --------- & -------- & ------ 33 & --------- & ---------- & & \\
\hline POG-015 & $1.89 \mathrm{aA}$ & $1.92 \mathrm{aA}$ & $2.04 \mathrm{aA}$ & $1.71 \mathrm{aB}$ & $1.09 \mathrm{aA}$ & $1.14 \mathrm{bA}$ & $\begin{array}{l}2.0713-0.1391 \mathrm{x}+0.0049 \mathrm{x}^{2} \\
\mathrm{R}^{2}=83.98 \%\end{array}$ \\
\hline POG-021 & $1.67 \mathrm{aA}$ & $2.06 \mathrm{aA}$ & $1.58 \mathrm{aB}$ & $1.85 \mathrm{aA}$ & $1.30 \mathrm{aA}$ & $1.47 \mathrm{aB}$ & $\begin{array}{l}1.7357+0.1142 \mathrm{x}- \\
0.0335 \mathrm{x}^{2}+0.0015 \mathrm{x}^{3} \\
\mathrm{R}^{2}=62.05 \%\end{array}$ \\
\hline \multirow[t]{2}{*}{$\mathrm{CV}(\%)$} & \multicolumn{6}{|c|}{8.88} & \\
\hline & \multicolumn{6}{|c|}{ a-guaiene (RRI: 1437) } & \\
\hline POG-015 & $6.38 \mathrm{aA}$ & $6.97 \mathrm{aA}$ & $6.80 \mathrm{aA}$ & $7.20 \mathrm{aA}$ & $4.20 \mathrm{bA}$ & $4.62 \mathrm{bA}$ & $\begin{array}{l}6.2763+0.8599 \mathrm{x}- \\
0.2170 \mathrm{x}^{2}+0.0098 \mathrm{x}^{3} \\
\mathrm{R}^{2}=96.50 \%\end{array}$ \\
\hline POG-021 & $5.87 \mathrm{aA}$ & $6.78 \mathrm{aA}$ & $6.83 \mathrm{aA}$ & $6.96 \mathrm{aA}$ & $6.14 \mathrm{aA}$ & $7.03 \mathrm{aA}$ & $\begin{array}{l}5.9908+0.6865 \mathrm{x}- \\
0.1290 \mathrm{x}^{2}+0.0056 \mathrm{x}^{3} \\
\mathrm{R}^{2}=93.65 \%\end{array}$ \\
\hline POG-015 & $6.38 \mathrm{aA}$ & $647 \mathrm{aA}$ & $6.75 \mathrm{aA}$ & $602 \mathrm{aA}$ & $4.14 \mathrm{bA}$ & $4.59 \mathrm{bA}$ & \\
\hline 21 & $5.87 \mathrm{aA}$ & $7.16 \mathrm{aA}$ & $6.21 \mathrm{aA}$ & $6.90 \mathrm{aA}$ & $5.30 \mathrm{aA}$ & $6.18 \mathrm{aA}$ & $\begin{array}{l}6.8955- \\
0.3933 \mathrm{x}+0.0151 \mathrm{x}^{2} \\
\mathrm{R}^{2}=80.62 \% \\
6.0567+0.6252 \mathrm{x}- \\
0.1405 \mathrm{x}^{2}+0.0063 \mathrm{x}^{3} \\
\mathrm{R}^{2}=65.53 \%\end{array}$ \\
\hline \multirow[t]{2}{*}{$\mathrm{CV}(\%)$} & \multicolumn{6}{|c|}{9.53} & \\
\hline & \multicolumn{6}{|c|}{ Seychellene (RRI: 1444) } & \\
\hline POG-015 & $3.70 \mathrm{aA}$ & $4.59 \mathrm{aA}$ & $3.91 \mathrm{aA}$ & $4.14 \mathrm{aA}$ & $2.88 \mathrm{bA}$ & $3.32 \mathrm{bA}$ & $\begin{array}{l}3.8610+0.3803 \mathrm{x}- \\
0.1000 \mathrm{x}^{2}+0.0046 \mathrm{x}^{3} \\
\mathrm{R}^{2}=81.29 \%\end{array}$ \\
\hline POG-021 & $3.69 \mathrm{aA}$ & $3.88 \mathrm{bA}$ & $4.14 \mathrm{aA}$ & $3.97 \mathrm{aA}$ & $4.08 \mathrm{aA}$ & $4.72 \mathrm{aA}$ & Ns \\
\hline POG-015 & $3.70 \mathrm{aA}$ & $3.78 \mathrm{bB}$ & $3.95 \mathrm{aA}$ & $3.48 \mathrm{bB}$ & $2.95 \mathrm{bA}$ & $3.33 \mathrm{bA}$ & $\begin{array}{l}3.9316-0.1595 x+0.0074 x^{2} \\
R^{2}=71.13 \%\end{array}$ \\
\hline POG-021 & $3.69 \mathrm{aA}$ & $4.35 \mathrm{aA}$ & $3.83 \mathrm{aA}$ & $4.03 \mathrm{aA}$ & $3.75 \mathrm{aA}$ & $4.21 \mathrm{aA}$ & Ns \\
\hline
\end{tabular}

São Cristóvão (SE), UFS, 2012; Means followed by the same lowercase letters in the column and uppercase letters between temperatures do not differ by the Scott-Knott's test $(\mathrm{p} \leq 0.05)$. 
Table 4. Contents of the chemical compounds $\alpha$-humulene, $\alpha$-patchoulene, and allo-aromadendrene of the essential oil of Patchouli (Pogostemon cablin) genotypes in function of storage time and storage temperatures of dry leaves.

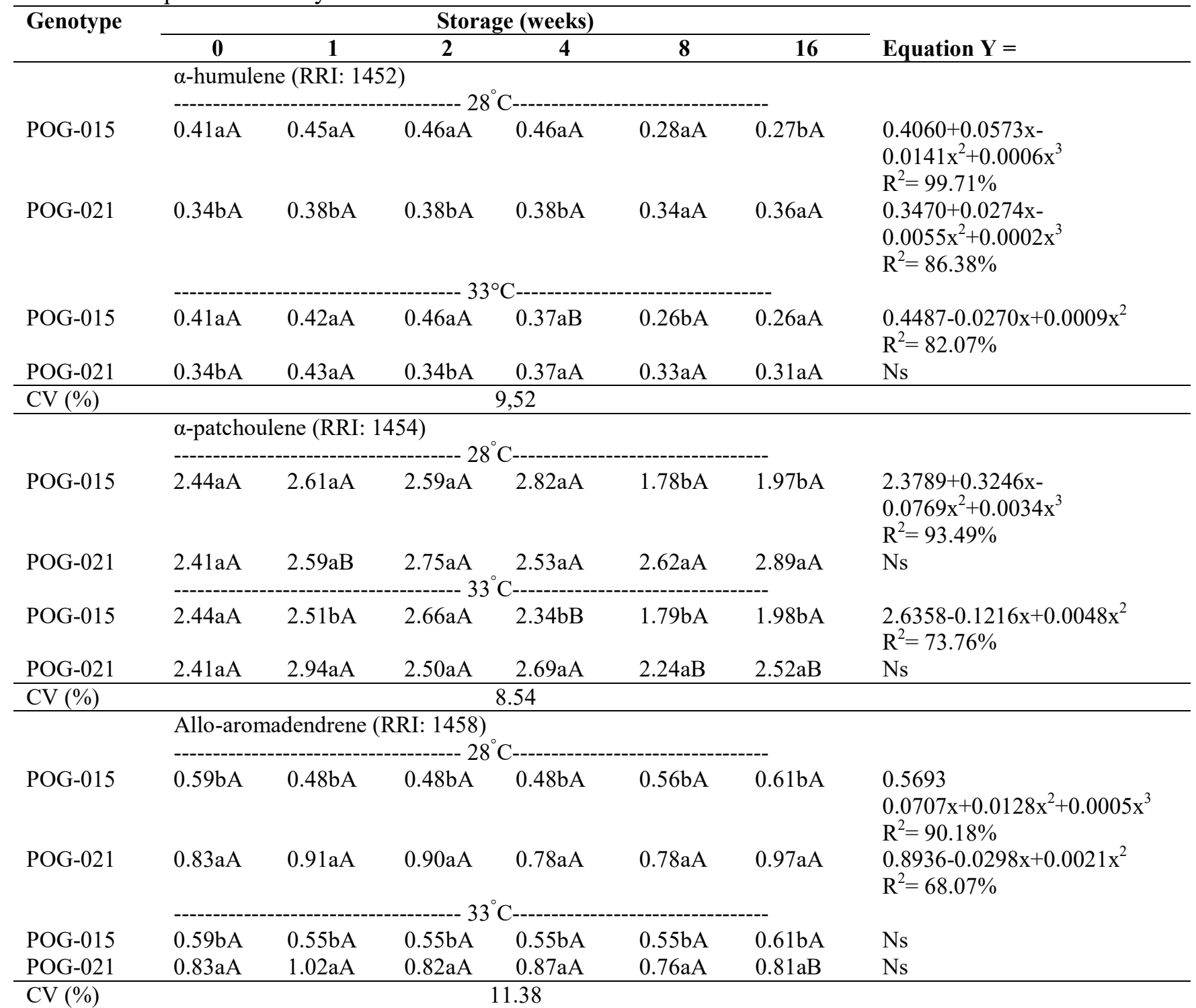

São Cristóvão (SE), UFS, 2012; Means followed by the same lowercase letters in each column and uppercase letters between temperatures do not differ by the Scott-Knott's test ( $\mathrm{p} \leq 0.05)$.

The highest content of pogostol $(7.72 \%)$ in POG-015 was obtained in the second week of storage at $33{ }^{\circ} \mathrm{C}$. Results are represented by a cubic equation (Table 6).

The compounds found in this study agree with what is commonly observed for patchouli essential oil. According to a review published exclusively with this aromatic species, the three compounds observed at the highest concentrations for most published studies are patchoulol, $\alpha$ bulnesene, and $\alpha$-guaiene (BEEK; JOULAIN 2018).
The storage time and the storage temperature influence the patchouli essential oil content.

The highest essential oil content of genotype POG-021 leaves was detected between the second and eighth weeks of storage at $28^{\circ} \mathrm{C}$.

Based on patchoulol, dry leaves of patchouli genotypes (POG-015 and POG-021) can be stored for up to eight weeks at $28{ }^{\circ} \mathrm{C}$ and $33{ }^{\circ} \mathrm{C}$ without altering the essential oil quality 
Table 5. Contents of the chemical compounds 9-epi- (E) caryophyllene and $\alpha$-bulnesene of the essential oil of Patchouli (Pogostemon cablin) genotypes in function of storage time and storage temperatures of dry leaves.

\begin{tabular}{|c|c|c|c|c|c|c|c|}
\hline \multirow[t]{2}{*}{ Genotype } & \multicolumn{6}{|c|}{ Storage (weeks) } & \multirow[b]{2}{*}{ Equation $Y=$} \\
\hline & $\mathbf{0}$ & 1 & 2 & 4 & 8 & 16 & \\
\hline & \multicolumn{6}{|c|}{ 9-epi-(E) caryophyllene (RRI: 1464) } & \\
\hline POG-015 & $0.78 \mathrm{aA}$ & $0.86 \mathrm{aA}$ & $0.85 \mathrm{aA}$ & $0.89 \mathrm{aA}$ & $0.55 \mathrm{bA}$ & $0.60 \mathrm{bA}$ & $\begin{array}{l}0.7677+0.1065 \mathrm{x}- \\
0.0257 \mathrm{x}^{2}+0.0011 \mathrm{x}^{3} \\
\mathrm{R}^{2}=97.24 \%\end{array}$ \\
\hline POG-021 & $0.69 \mathrm{aA}$ & $0.76 \mathrm{aA}$ & $0.78 \mathrm{aA}$ & $0.76 \mathrm{bA}$ & $0.74 \mathrm{aA}$ & $0.82 \mathrm{aA}$ & Ns \\
\hline POG-015 & $0.78 \mathrm{aA}$ & $0.79 \mathrm{aA}$ & $0.85 \mathrm{aA}$ & $0.74 \mathrm{aB}$ & $0.52 \mathrm{bA}$ & $0.59 \mathrm{bA}$ & $\begin{array}{l}0.8470- \\
0.0466 \mathrm{x}+0.0018 \mathrm{x}^{2} \\
\mathrm{R}^{2}=74.54 \%\end{array}$ \\
\hline POG-021 & $0.69 \mathrm{aA}$ & $0.85 \mathrm{aA}$ & $0.70 \mathrm{bA}$ & $0.79 \mathrm{aA}$ & $0.64 \mathrm{aA}$ & $0.73 \mathrm{aA}$ & Ns \\
\hline \multirow[t]{2}{*}{$\mathrm{CV}(\%)$} & \multicolumn{6}{|c|}{8.73} & \\
\hline & \multicolumn{5}{|c|}{$\alpha$-bulnesene (RRI: 1509) } & & \\
\hline POG-015 & $9.27 \mathrm{aA}$ & $10.00 \mathrm{aA}$ & $10.20 \mathrm{aA}$ & $10.17 \mathrm{aA}$ & $6.78 \mathrm{aA}$ & $7.16 \mathrm{aA}$ & $\begin{array}{l}9.1980+1.0736 \mathrm{x}- \\
0.2674 \mathrm{x}^{2}+0.0120 \mathrm{x}^{3} \\
\mathrm{R}^{2}=99.30 \%\end{array}$ \\
\hline POG-021 & $5.71 \mathrm{bA}$ & $8.55 \mathrm{aA}$ & $9.18 \mathrm{aA}$ & $9.51 \mathrm{aA}$ & $8.54 \mathrm{aA}$ & $9.67 \mathrm{aA}$ & $\begin{array}{l}6.1477+2.0627 x- \\
0.3302 x^{2}++0.0134 x^{3} \\
R^{2}=91.85 \%\end{array}$ \\
\hline POG-015 & $9.27 \mathrm{aA}$ & $9.49 \mathrm{aA}$ & $9.84 \mathrm{aA}$ & $6.48 \mathrm{aB}$ & 7.09aA & $7.30 \mathrm{aA}$ & $\begin{array}{l}9.7909- \\
0.6210 \mathrm{x}+0.0292 \mathrm{x}^{2} \\
\mathrm{R}^{2}=66.06 \%\end{array}$ \\
\hline POG-021 & $5.71 \mathrm{bA}$ & $9.37 \mathrm{aA}$ & $8.70 \mathrm{aA}$ & $9.06 \mathrm{aA}$ & $7.80 \mathrm{aA}$ & $8.58 \mathrm{aA}$ & $\begin{array}{l}6.4646+1.8311 \mathrm{x}- \\
0.3157 \mathrm{x}^{2}+0.0131 \mathrm{x}^{3} \\
\mathrm{R}^{2}=68.05 \%\end{array}$ \\
\hline
\end{tabular}

São Cristóvão (SE), UFS, 2012; Means followed by the same lowercase letters in the column and uppercase letters between temperatures do not differ by the Scott-Knott's test $(\mathrm{p} \leq 0.05)$.

Table 6. Contents of the chemical compounds caryophyllene oxide, pogostol, and patchoulol of the essential oil of Patchouli (Pogostemon cablin) genotypes in function of storage time and storage temperatures of dry leaves.

\begin{tabular}{|c|c|c|c|c|c|c|c|}
\hline \multirow[t]{2}{*}{ Genotype } & \multicolumn{6}{|c|}{ Storage (weeks) } & \multirow[b]{2}{*}{ Equation $Y=$} \\
\hline & $\mathbf{0}$ & 1 & 2 & 4 & 8 & 16 & \\
\hline & Caryopl & ne oxide ( & 1582) & & & & \\
\hline POG-015 & $0.65 \mathrm{aA}$ & $0.61 \mathrm{aA}$ & $0.73 \mathrm{aB}$ & $0.79 \mathrm{aB}$ & $0.70 \mathrm{bA}$ & $1.37 \mathrm{aB}$ & $\begin{array}{l}0.6817- \\
0.0139 x+0.0034 x^{2} \\
R^{2}=92.52 \%\end{array}$ \\
\hline POG-021 & $0.38 \mathrm{bA}$ & $0.83 \mathrm{aA}$ & $0.65 \mathrm{aA}$ & $0.87 \mathrm{aB}$ & $1.01 \mathrm{aA}$ & $1.58 \mathrm{aB}$ & $\begin{array}{l}0.5593+0.0632 x \\
\mathrm{R}^{2}=89.64 \%\end{array}$ \\
\hline POG-015 & $0.65 \mathrm{aA}$ & $0.72 \mathrm{bA}$ & $1.26 \mathrm{aA}$ & $1.23 \mathrm{aA}$ & $0.72 \mathrm{bA}$ & $1.71 \mathrm{bA}$ & $\begin{array}{l}0.5701+0.4265- \\
0.0793 x^{2}+0.0035 x^{3} \\
R^{2}=92.62 \%\end{array}$ \\
\hline POG-021 & $0.38 \mathrm{bA}$ & $1.01 \mathrm{aA}$ & $0.63 \mathrm{bA}$ & $1.36 \mathrm{aA}$ & $0.99 \mathrm{aA}$ & $2.06 \mathrm{aA}$ & $\begin{array}{l}0.4213+0.3949 x- \\
0.0614 x^{2}+0.0026 x^{3} \\
R 2=87.24 \%\end{array}$ \\
\hline
\end{tabular}


Influence of storage...

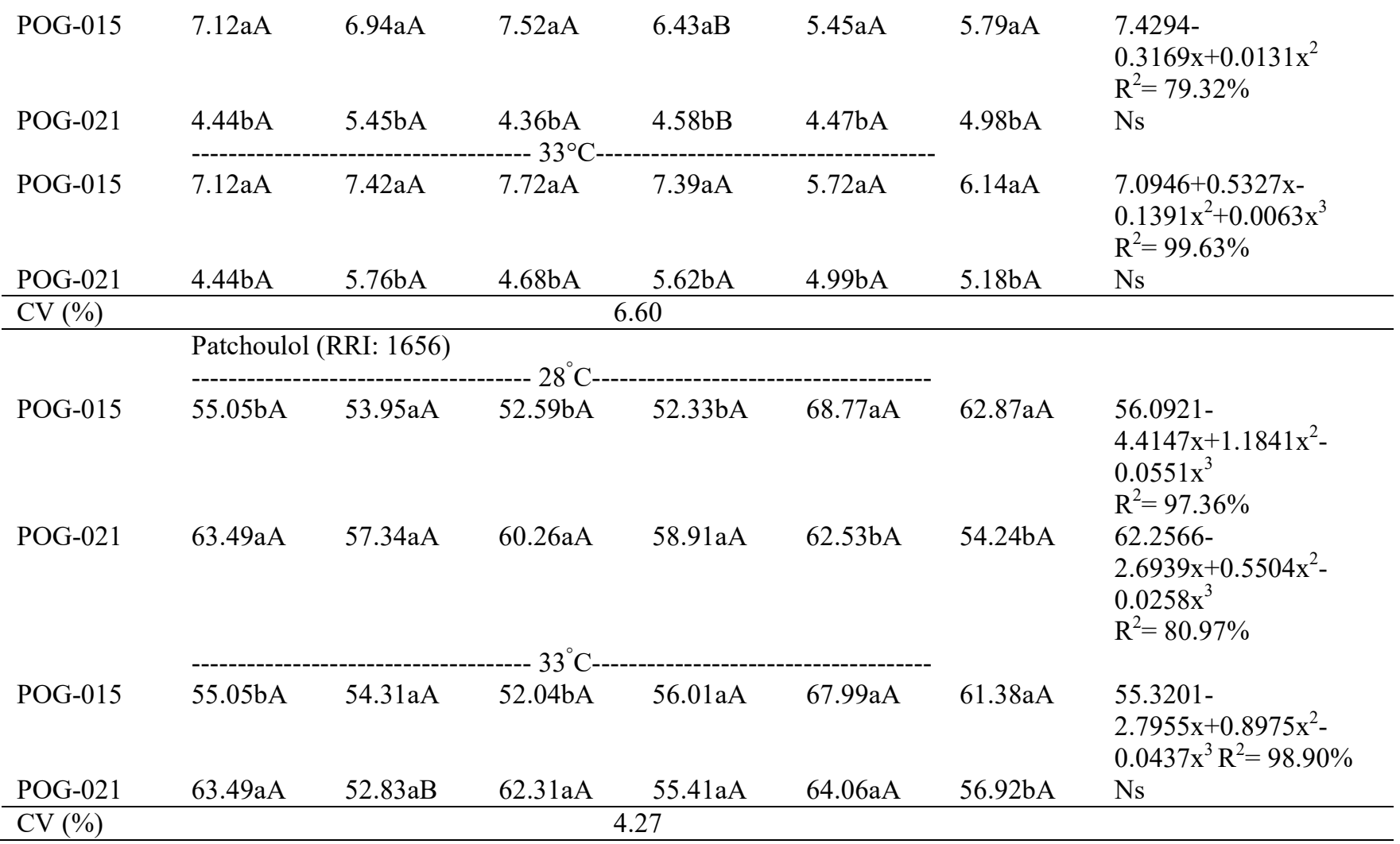

São Cristóvão (SE), UFS, 2012; Means followed by the same lowercase letters in each column and uppercase letters between temperatures do not differ by the Scott-Knott's test $(\mathrm{p} \leq 0.05)$.

RESUMO: Patchouli [Pogostemon cablin (Blanco) Benth.] é uma planta pertencente à família Lamiaceae, e seu óleo essencial é utilizado nas indústrias de perfumes e cosméticos. O objetivo do trabalho foi avaliar a influência do tempo e temperaturas de armazenamento das folhas secas no teor e na composição química do óleo essencial de patchouli. O delineamento experimental foi o inteiramente casualizado em esquema fatorial $6 \times 2 \times 2$, testando tempo de armazenamento $(0,1,2,4,8$ e 16 semanas), temperatura de armazenamento $\left(28^{\circ} \mathrm{C}\right.$ e $\left.33^{\circ} \mathrm{C}\right)$ de folhas secas de dois genótipos (POG-015 e POG-021) de patchouli. As variáveis avaliadas foram o teor e a composição química do óleo essencial e a identificação dos fungos que se desenvolveram durante o armazenamento. Os resultados mostraram que o armazenamento influenciou significativamente o teor de óleo essencial. Dos compostos identificados, o patchoulol foi o composto majoritário nos dois genótipos, variando de 55,05\% a 68,77\% (POG-15) e 52,83\% a 64,06\% (POG-021). Baseado no patchoulol, folhas secas dos genótipos (POG-015 e POG-021) de patchouli podem ser armazenadas por um período de até oito semanas em temperatura de 28 e $33^{\circ} \mathrm{C}$, sem alterar a qualidade do óleo essencial.

PALAVRAS-CHAVE: Pogostemon cablin. Pós-colheita. Patchoulol. Composição química,

\section{REFERENCES}

ADAMS, R. P. Identification of essential oil components by gas chromatography/mass spectroscopy. $4^{\text {th }}$ ed., Allured: Carol Stream, 2007. 804p.

ALBUQUERQUE, E. L. D.; LIMA, J. K. A.; SOUZA, F. H. O.; INDIRA M.A. SILVA, I. M. A.; SANTOS, A. A.; ARAÚJO, A. P. A.; BLANK, A. F.; LIMA, R. N.; ALVES, P. B.; BACCI, L. Insecticidal and repellence activity of the essential oil of Pogostemon cablin against urban ants species. Acta Tropica, v. 127 p. $181-186$, apr. 2013. http://dx.doi.org/10.1016/j.actatropica.2013.04.011 
ALVES, M. F.; BLANK, A. F.; ANDRADE, T. M.; NIZIO, D. A. C.; SAMPAIO, T. S.; NASCIMENTO JUNIOR, A. F. content and chemical composition of the essential oil of Myrcia lundiana kiaersk in different drying times. Biosciene Journal, Uberlândia, v. 34, n. 3, p. 623-628, may/june 2018.

http://dx.doi.org/10.14393/BJ-v34n3a2018-39371

ANONIS, D. P. Woody notes in perfumery, patchouly oil, absolute and aroma chemicals: Part I. Perfumer \& Flavorist, v. 31, p. 36-39, nov. 2006. Disponível<

http://www.media.allured.com/documents/PF_31_11_036_04.pdf $>$ Acesso em: 12 de agosto de 2013.

BEEK, V. T. A.; JOULAIN D. The essential oil of patchouli, Pogostemon cablin: A review. Flavour and Fragrance Journal, v. 33, p. 6-51, 2018. https://doi.org/10.1002/ffj.3418

BIZZO, H. R.; HOVELL, A. M. C.; REZENDE, C. M. Óleos essenciais no Brasil: aspectos gerais, desenvolvimento e perspectivas. Química Nova, São Paulo, v. 32, p. 588-594, apr. 2009.

http://dx.doi.org/10.1590/S0100-40422009000300005

CORREA, R. M.; BERTOLUCCI, S. K. V.; PINTO, J. E. B. P.; REIS, E. S.; ALVES, T. L. Teor de óleo essencial e caracterização organoléptica de folhas de assa-peixe submetidas a diferentes métodos de secagem. Ciência e Agrotecnologia, Lavras, v. 28, n. 2, p. 339-344, mar/apr.2004. http://dx.doi.org/10.1590/S141370542004000200013.

EHLERT, P. A. D.; BLANK, A. F.; ARRIGONI-BLANK, M. F.; PAULA, J. W. A.; CAMPOS, D. A.; ALVIANO, C. S. Tempo de hidrodestilação na extração de óleo essencial de sete espécies de plantas medicinais. Revista Brasileira de Plantas Medicinais, Botucatu, v. 8, n. 2, p. 79-80, 2006.

http://ri.ufs.br/handle/123456789/1548

FERREIRA, D. F. Sisvar: a computer statistical analysis system. Ciência e Agrotecnologia, Lavras, v. 35, n. 6, p.1039-1042, nov/dec. 2011. http://dx.doi.org/10.1590/S1413-70542011000600001

MARCHESE, J. A., FIGUEIRA, G. M. O uso de tecnologias pré e pós-colheita e boas práticas agrícolas na produção de plantas medicinais e aromáticas. Revista Brasileira de Plantas Medicinais, Botucatu, v. 7, n. 3, p. 86-96, 2005. http://repositorio.unicamp.br/jspui/bitstream/REPOSIP/93640/1/2-s2.0-23844495644.pdf

NIZIO, D. A. C.; BLANK, A. F.; SAMPAIO, T. S.; BRITO, F. A.; ANDRADE, T. M.; ARRIGONI-BLANK, M. F.; MARIA, A. N. Distillation methods affect the chemical composition of Varronia curassavica Jacq. essential oil? Bioscience Journal, Uberlândia, v. 34, n. 3, p. 629-639, may/june 2018.

http://dx.doi.org/10.14393/BJ-v34n3a2018-39372

PAVELA, R. Insecticidal activity of some essential oils against larvae of Spodoptera littoralis. Fitoterapia, v. 76, p. 691-696, oct. 2005. http://dx.doi.org/10.1016/j.fitote.2005.06.001

SALERNO, A. R.; REBELO, A. M.; SILVA JUNIOR, A. A. Plantas aromáticas para cultivo em Santa Catarina. Agropecuária Catarinense, Florianópolis, v. 17, n. 2, p. 46-49, 2004.

SANT'ANA, T. P. C.; BLANK, A. F; VIEIRA, S. D; ARRIGONI-BLANK, M. F. Influência do armazenamento de folhas secas no óleo essencial de patchouli (Pogostemon cablin Benth.). Química Nova, São Paulo, v. 33, n. 6, p. 1263-1265, jun. 2010. http://dx.doi.org/10.1590/S0100-40422010000600008.

SINGH, M.; SHARMA, S.; RAMESH, S. Herbage, oil yield and oil quality of patchouli [Pogostemon cablin (Blanco) Benth.] influenced by irrigation, organic mulch and nitrogen application in semi-arid tropical climate. Industrial Crops and Products, v. 16, n. 2, p. 101-107, feb. 2002. https://doi.org/10.1016/S09266690(02)00013-4 
SWAMY, M. K.; SINNIAH, A. R. "A comprehensive review on the phytochemical constituents and pharmacological activities of Pogostemon cablin Benth. An aromatic medicinal plant of industrial importance". Molecules, v. 20, n. 5, p. 8521-8547, may 2015. http://dx.doi.org/10.3390/molecules20058521.

TSAI, Y.; HSU, H.; YANG, W.; TSAI, W.; CHEN, C.; WATANABE, T. $\alpha$-bulnesene, a PAF inhibitor isolated from the essential oil of Pogostemon cablin. Fitoterapia, v. 78, p. 7-11, jan. 2007.

https://doi.org/10.1016/j.fitote.2006.09.016

VAN DEN DOOL, H.; KRATZ, P. D. A generalization of the retention index system including linear temperature programmed gas-liquid partition chromatography. Journal of Chromatography, USA, v. 11, p. 463-471, aug. 1963. https://doi.org/10.1016/S0021-9673(01)80947-X

ZHU, B. C. R.; HENDERSON, G.; YU, Y.; LAINE, R. A. Toxicity and repellency of patchouli oil and patchouli alcohol against formos an subterranean termites Coptotermes formosanus Shiraki (Isoptera: Rhinotermitidae). Journal Agricultural and Food Chemistry, v. 51, p. 4585-4588, july 2003. https://doi.org/10.1021/jf0301495 